\title{
Wild Mixed Culture Microalgae Biomass from UI Agathis Small Lake Harvested Directly using an Ultrasound Harvesting Module as Biofuel Raw Material
}

Nining Betawati Prihantini ${ }^{*}$, Fadhlurrahman Maulana ${ }^{1}$, Wisnu Wardhana ${ }^{1}$, Noverita Dian Takarina ${ }^{1}$, Erwin Nurdin ${ }^{1}$, Sri Handayani², Nasruddin ${ }^{3}$, Gadis Sri Haryani ${ }^{4}$

${ }^{1}$ Department of Biology, Faculty of Mathematics and Natural Sciences, Universitas Indonesia, Kampus UI Depok, Depok 16424, Indonesia

${ }^{2}$ Department of Chemistry, Faculty of Mathematics and Natural Sciences, Universitas Indonesia, Kampus UI Depok, Depok 16424, Indonesia

${ }^{3}$ Department of Mechanical Engineering, Faculty of Engineering, Universitas Indonesia, Kampus UI Depok, Depok 16424, Indonesia

${ }^{4}$ Research Center for Limnology, National Research and Innovation Agency (BRIN), Cibinong, Bogor 16911, Indonesia

\begin{abstract}
A follow-up study on the use of ultrasonic sound for harvesting a mixed culture of microalgae from a small lake for biofuel feedstock has been carried out. Observations were made at the Agathis small lake of Universitas Indonesia during the rainy season. The aim of the study was to determine the microalgae community members in Agathis with the potential for lipid production and to determine the lipid concentration in the mixed culture biomass from Agathis, harvested using an ultrasound harvesting module (UHM). The results showed that there were 11 species of microalgae from 10 genera and four classes. Nine of the 11 species of microalgae found in Agathis have the ability to produce lipids. The total biomass obtained from water samples from all stations in Agathis was $25.18 \mathrm{~g}$, and the average lipid content of the biomass of Agathis water samples in March 2020 was 55.5\%.
\end{abstract}

Keywords: Lipid content; Microalgae; Mixed culture; UI Agathis small lake; Ultrasound Harvesting Module (UHM)

\section{Introduction}

Biofuels are energy sources made from newly grown biomass (plants, animal byproducts, or microorganisms). There are four generations of biofuels based on the biomass sources used, their limitations as a renewable energy source, and their technological advances. Based only on the biomass sources used, there are three generations of biofuels, i.e., the first generation uses biomass that is also a food source, the second uses biomass from non-food sources, and the third uses biomass from microorganisms. Meanwhile, the fourth generation of biofuels is more focused on genetically modified microorganisms (Alalwan et al., 2019; Mat Aron et al., 2020).

Third-generation biofuels use algae as an energy source (Singh et al., 2011; Cercado et., 2018). Microalgae can be grown using sewage, wastewater, and salt water, such as from 
oceans or salt lakes. Microalgae lipids can compete with petroleum in production costs if the percentage of lipid produced by microalgae is about $60 \%$ of the biomass (Shen et al., 2009).

One of the biggest obstacles to the production of renewable fuels using microalgae is the need for more water than cultivated plants (Singh et al., 2011). Several ways to overcome microalgae culture have been carried out by developing photobioreactors (Rizaldi et al., 2019; Santoso et al., 2020). However, the problem of the need for water is still an obstacle. To cope with the significant water needs, one of the water sources that can be used is wastewater. Wastewater can be obtained continuously and contains many nutrients. Nutrient levels in wastewater cause many microalgae to grow within (Dalrymple et al., 2013).

A mixed culture is a culture in which the inoculum always consists of two or more organisms. Mixed cultures may consist of a known species to the exclusion of all others, or they may consist of a mixture of unknown species. Several researchers have used mixed cultures as a tool to study biochemical and ecological interactions or to culture new microorganisms (Little et al., 2008). Mixed cultures can occur naturally in nature, such as in lakes (Sathish and Sims, 2012). One of the small lakes in the Universitas Indonesia (UI) area is Agathis (Direktorat Umum dan Fasilitas Universitas Indonesia, 2009).

In 2003, 2006, and 2011, 16 microalgae genera were found in Agathis (Prihantini and Wardhana, 2016). Of those 16 genera of microalgae, 10 have been studied, and their lipid contents are known (Mendes et al., 2006; Prabakaran and Ravindran, 2011; Mousavi et al., 2018; Khan et al., 2020). The study showed that most of the microalgae from Agathis could produce lipids. However, the overall ability of the Agathis microalgae community to produce lipids as a mixed culture was only studied modestly in the dry season. The Agathis microalgae community in the dry season is known to produce lipids, the percentage of which is $23 \%$ by weight of the biomass (Maulana et al., 2021).

Seasonal changes can affect the state of cultured microalgae, as they lead to changes in temperature and daily light intensity (Brönmark and Hansson, 2017). Microalgae that experience growth inhibition due to environmental stress cause decreased protein production and increase lipid storage. This phenomenon causes less microalgae biomass to be produced with more lipid content per g of biomass (Karima et al., 2018).

The lipid extraction yield obtained is highly dependent on the method of harvesting the microalgae biomass, whether by filtration and flocculation (Fasaei et al., 2018). In addition, there is a method with the working principle of using ultrasonic waves, i.e., an ultrasound harvesting module (UHM). The UHM uses ultrasonic waves from two sources facing each other to collect microalgae cells in water. Microalgae cells collected due to ultrasonic waves will settle due to gravity. The UHM method is also still in the experimental stage (Ardiansyah et al., 2020).

The study was conducted to observe the microalgae community in Agathis and to determine the potential for lipid production of the microalgae community during the rainy season. This study also aimed to determine the concentration of lipids in the mixed culture biomass from Agathis during the rainy season harvested using UHM.

\section{Methods}

\subsection{Sampling Location and Research Time}

The location for sampling was Agathis small lake (Situ Agathis), UI Campus, Depok, West Java. Agathis is located at the beginning of the cascade pond system of UI, which includes Agathis, Mahoni, Puspa, Ulin, and Salam. This research observed the location of the water entrance into the UI area. Sample observations and data analysis were carried out at 
the Department of Biology, Faculty of Mathematics and Natural Sciences, UI. Sampling was carried out on March 13, 2020, and the sampling location can be seen in Figure 1.

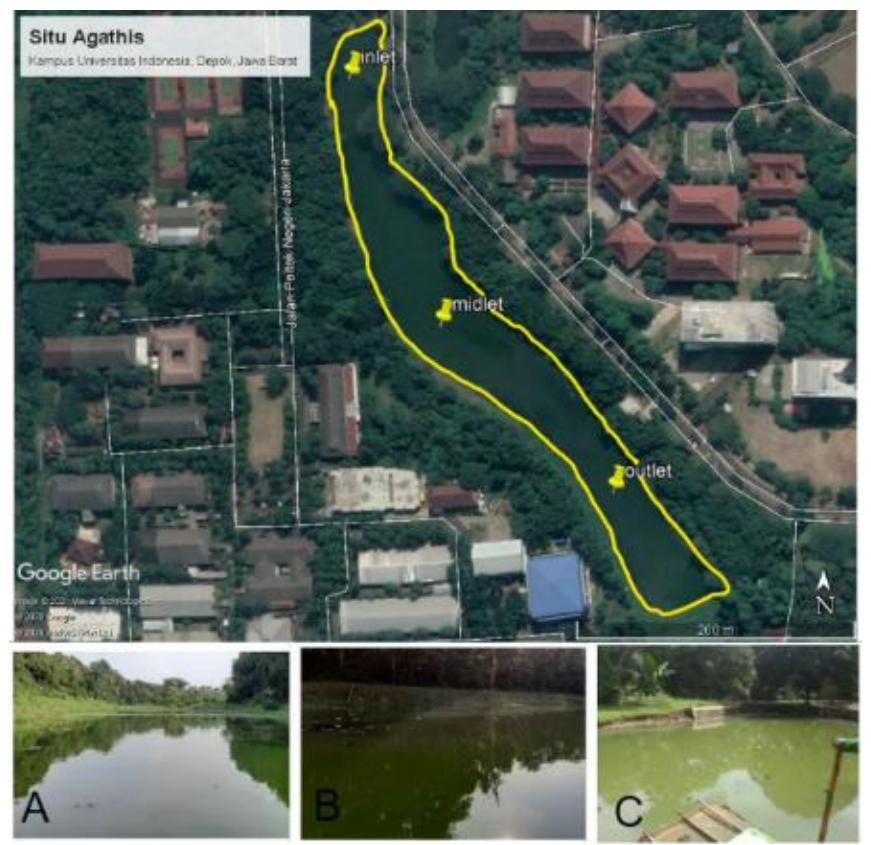

Figure 1 Sampling stations in Agathis small lake of Universitas Indonesia (UI) Campus, Depok, West Java. Note: N. North; A. inlet; B. midlet, C. outlet. Bar: 200 m (Source: Google Earth)

\subsection{Water Sampling and Measurement of Environmental Parameters}

Samples for identification from each station (inlet, midlet, outlet) were taken using a plankton net (mesh $20 \mu \mathrm{m}$, diameter $25 \mathrm{~cm}$ ). Sampling was carried out horizontally as far as 1 meter below the water surface. Sampling was done four times. Samples in three bottles (Film Canister Fujifilm $25 \mathrm{ml}$ ) were preserved by giving $40 \%$ formalin until the sample contained $4 \%$ formalin, while one sample was not preserved. Environmental parameters, such as temperature (thermometer $0360 \mathrm{Hg}$ ), dissolved oxygen (DO Vernier), nitrate content (Vernier), phosphate content (phosphate Colorimeter Hanna Instruments), water flow velocity (Vernier), depth, and water clarity (La Motte Secchi Disk) were measured and recorded from each point. Weather and rainfall data are taken as secondary data from Badan Meteorologi Klimatologi dan Geofisika (BMKG, 2019).

\subsection{Microalgae Identification of Sample}

The samples in vials were taken using a Pasteur pipette. The sample was dropped on the object glass as much as $0.04 \mathrm{ml}$ and closed using a cover slip. The sample was then observed under a microscope. The observed microalgae were identified using the identification books of Edmonson (1960), Bold and Wynne (1985), Pentecost (1984), Geitler (1985), Hoek van den et al. (1995), and Whitton (2002), and they were counted and photographed. The number of microalgae per species and overall is presented in the form of tables.

\subsection{Harvesting using UHM and Lipid Extraction using the Bligh \& Dyer Method}

As much as $20 \mathrm{~L}$ of water samples was taken for extraction from each station. Samples were then divided into large sample bottles with as much as $2 \mathrm{~L}$ each. The sample was filtered through a sieve with a mesh size of 60 to separate microalgae samples from zooplankton. The filtered sample was inserted into the UHM (Ardiansyah et al., 2020). The UHM then switched on for 20 min for harvesting. Microalgae biomass will settle after 20 min and can be decanted. The decanted biomass was weighed, and the obtained biomass 
was centrifuged to form pellets and supernatants. Lipid from pellets was extracted from the pellet through a modified Bligh and Dyer method (Bligh and Dyer, 1959). The equipment used includes a centrifuge (B-One 6015I Centrifuge), sonicator (Branson CPX2800H Sonicator), and scale (Precisa XB-220A analytical balance). The method of harvesting samples using the UHM and the method of extracting lipids from the biomass samples can be seen in Figure $2 a$ and Figure $2 b$.

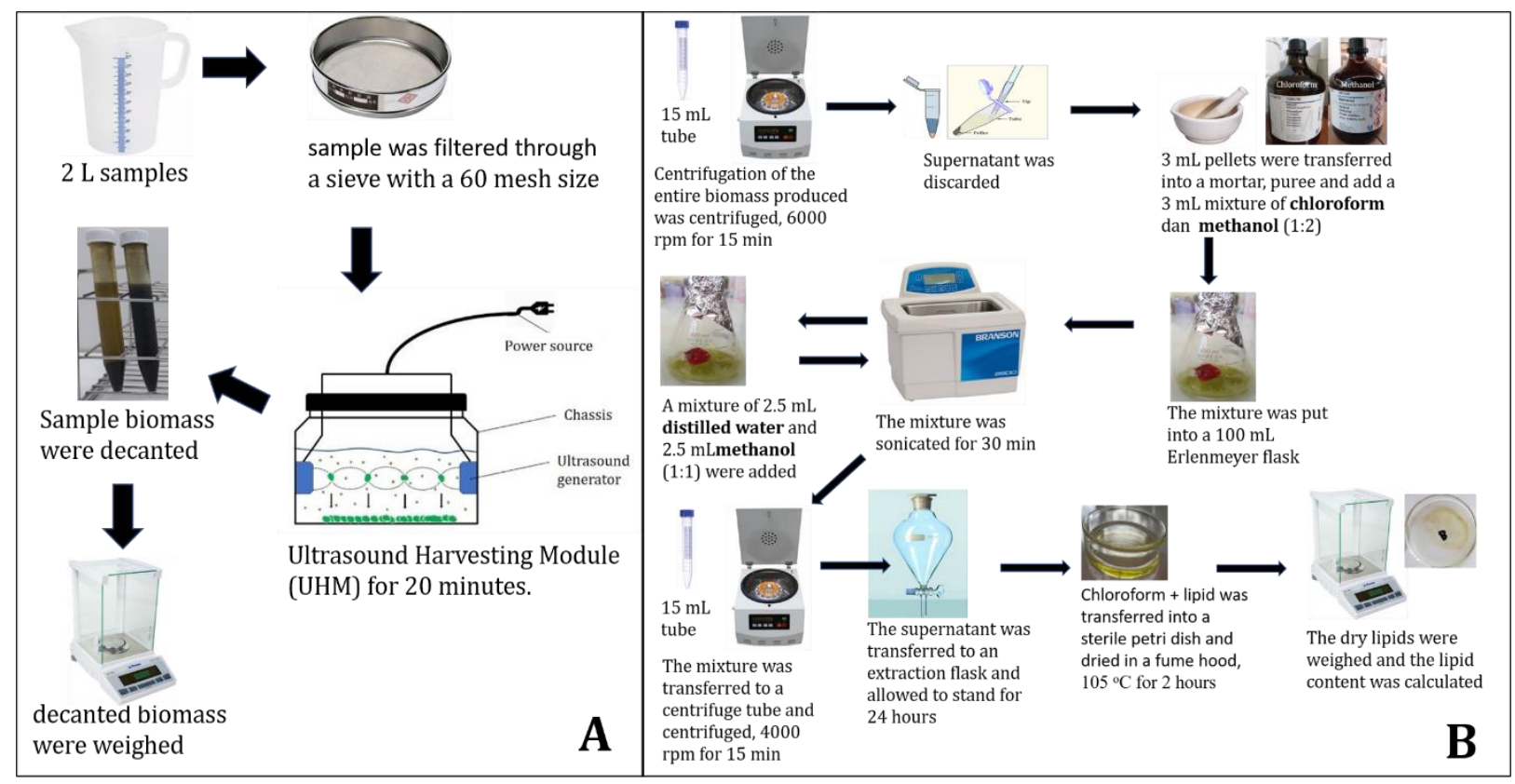

Figure 2 (a) Harvesting method of microalgae mixed-culture samples with UHM; (b) Lipid extraction method with modified Bligh and Dyer method

\subsection{Analysis and Processing of the Data}

Data concerning the lipid production from the biomass were presented descriptively and compared with the amount and lipid production capacity of each microalgae species that was identified based on the literature. Sample enumeration was carried out using the subsample method, and data processing was carried out using the formula for abundance, percentage of dominance, and lipid content of biomass. Abundance was calculated using Equation 1 (APHA, 2005).

$$
N=Z x \frac{X}{Y} x \frac{1}{V}
$$

where $N$ is the average microalgae (cells/L), $Z$ is the number of microalgae cells, $X$ is the sample volume (mL), $Y$ is the subsample volume $(\mathrm{mL})$, and $V$ is the volume of filtered water (L).

The percentage of dominance was calculated using Equation 2 (Cox, 1995).

$$
D i=\frac{N i}{N} \times 100 \%
$$

where $D_{i}$ is the percentage of dominance of microalgae, $N_{i}$ is the number of individuals of type I, and $N$ is the total number of microalgae species.

The lipid content of the biomass was calculated using Equation 3 (Li et al., 2008).

$$
L C=\frac{D L P}{D C W} \times 100 \%
$$

where $L$ stands for lipid percentage, $D L P$ for dry lipid profile or dry lipid weight (g), and $D C W$ for dry cellulate weight/dry biomass weight $(\mathrm{g})$. 
In addition, theoretical lipid levels can be estimated based on previous studies. The theoretical lipid content was obtained from the value of microalgae dominance $\left(D_{i}\right)$ multiplied by the lipid content based on the literature or previous research (Phatarpekar et al., 2000). The theoretical lipid content calculation is shown in Equation 4.

$$
T L C=D i x L C
$$

where $D_{i}$ is the microalgae dominance, $T L C$ is the theoretical lipid content, and $L C$ is the lipid content based on the literature.

\section{Results and Discussion}

\subsection{Physical-Chemical Data of Agathis in the Rainy Season}

The average temperature of Agathis was quite warm, at $30.6^{\circ} \mathrm{C}$. The warm water temperature could be due to the sunny weather on the day of sampling. The degree of acidity $(\mathrm{pH})$ of Agathis water is considered optimal for the growth of microalgae biomass and supports the production of microalgae lipids to a certain degree. The average degree of acidity at Agathis was close to neutral at 6.7. In the mapping of basic rainfall (per 10 days) by BMKG, Depok and the southern tip of Jakarta are located in the Java Monsoon Zone No. 61. The average daily rainfall based on this mapping was $65 \mathrm{~mm}$ per square meter (BMKG, 2019).

\subsection{Identification Results of Microalgae from Agathis}

Eleven (11) species of microalgae were identified from the Agathis water samples. The 11 species of microalgae belong to four classes, namely, Chlorophyceae, Euglenophyceae, Cyanophyceae/Cyanobacteria, and Bacillariophyceae, and they include Eudorina sp., Closterium sp., Scenedesmus sp., Euglena viridis, Euglena spirogyra, Phacus sp., Trachelomonas sp., Arthrospira sp., Oscillatoria sp., Limnothrix sp., and Pinnularia sp. The two species of microalgae in Agathis were not evenly distributed throughout the small lake. The microalgae of Arthrospira sp. could only be found at the inlet, and Scenedesmus sp. could only be found in the midlet and outlet. Documentation of identified microalgae found in Agathis can be seen in Figure 3.

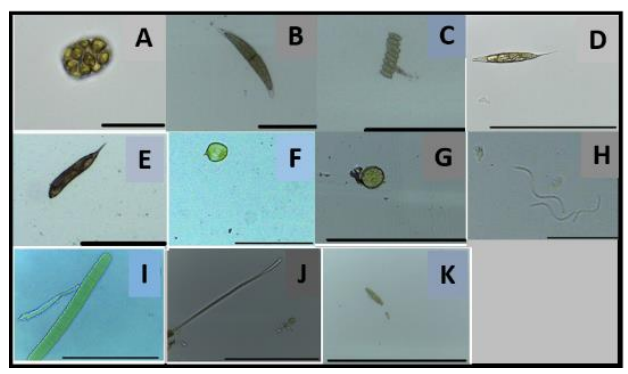

Figure 3 Microalgae of Agathis Lake: (A) Eudorina sp.; (B) Closterium sp.; (C) Scenedesmus sp.; (D) Euglena viridis; (E) Euglena spirogyra; (F) Phacus sp.; (G) Trachelomonas sp.; (H) Arthrospira sp.; (I) Oscillatoria sp.; (J) Limnothrix sp.; (K) Pinnularia sp. Bar = $50 \mu \mathrm{m}$

\subsection{Number of Microalgae and Community of Microalgae in Agathis}

The average total number of microalgae in Agathis was 7,472.5 plankter $/ \mathrm{m}^{3}$. The most common species of microalgae found in Agathis was Eudorina sp. The average number of Eudorina sp. in Agathis was 6,774.0 plankter $/ \mathrm{m}^{3}$. The least common species of microalgae found in Agathis is Arthrospira sp. The species Arthrospira sp. was only found in the inlet area, comprising as much as 0.5 plankter $/ \mathrm{m}^{3}$. The microalgae community of Agathis was dominated by Eudorina sp, whose average percentage of dominance in Agathis was 
$90.652 \%$. The calculation of the number of microalgae plankters and the percentage of microalgae dominance in Agathis can be seen in Table 1.

Table 1 Plankter number and dominance percentage of microalgae in Agathis

\begin{tabular}{|c|c|c|c|c|c|c|c|c|}
\hline \multirow{2}{*}{ Classes and Species } & \multicolumn{4}{|c|}{ Plankter Number $/ \mathrm{m}^{3}$} & \multicolumn{4}{|c|}{ Dominance Percentage (\%) } \\
\hline & Inlet & Midlet & Outlet & Average & Inlet & Midlet & Outlet & Average \\
\hline \multicolumn{9}{|l|}{ Chlorophyceae } \\
\hline Eudorina sp. & $10,607.4$ & $7,361.1$ & $2,353.5$ & $6,774.0$ & 91.296 & 90.819 & 84.328 & 90.652 \\
\hline Closterium sp. & 54.1 & 16.5 & 4.5 & 25.0 & 0.658 & 0.206 & 0.161 & 0.335 \\
\hline Scenedesmus sp. & - & 1.5 & 1.5 & 1.0 & - & 0.018 & 0.053 & 0.013 \\
\hline \multicolumn{9}{|l|}{ Euglenophyceae } \\
\hline Euglena viridis & 118.7 & 141.2 & 96.1 & 118.7 & 1.407 & 1.764 & 3.284 & 1.588 \\
\hline Euglena spirogyra & 61.6 & 31.5 & 34.5 & 32.2 & 0.555 & 0.395 & 1.238 & 0.431 \\
\hline Phacus sp. & 109.7 & 52.6 & 76.6 & 79.6 & 1.058 & 0.600 & 2.907 & 1.065 \\
\hline Trachelomonas sp. & 7.5 & 36.0 & 4.5 & 16.0 & 0.064 & 0.394 & 0.163 & 0.214 \\
\hline \multicolumn{9}{|l|}{ Cyanophyceae } \\
\hline Arthrospira sp. & 1.5 & - & - & 0.5 & 0.012 & - & - & 0.006 \\
\hline Oscillatoria sp. & 423.8 & 256.9 & 82.6 & 254.4 & 3.163 & 3.698 & 2.961 & 3.405 \\
\hline Limnothrix sp. & 163.8 & 138.2 & 72.1 & 124.7 & 1.407 & 1.651 & 2.584 & 1.669 \\
\hline \multicolumn{9}{|l|}{ Bacillariophyceae } \\
\hline Pinnularia sp. & 43.5 & 30.0 & 64.6 & 46.0 & 0.374 & 0.450 & 2.315 & 0.616 \\
\hline Total & $11,591.8$ & $8,066.0$ & $2,790.8$ & $7,472.5$ & & & & \\
\hline
\end{tabular}

\subsection{Lipid Extraction Results from Agathis Water Samples}

The average lipid content of the whole of Agathis was $55.5 \%$ per g of biomass. Samples from the inlet area had the highest lipid content, at $67.7 \%$, while samples from the midlet area had the least lipid content, at $44.1 \%$. The results of lipid extraction can be seen in Table 2. The least amount of biomass obtained from the inlet was $7.76 \mathrm{~g}$, and most of the biomass was obtained from the outlet, as much as $8.73 \mathrm{~g}$.

Samples from the inlet contained the least biomass but the most lipids. This can indicate the presence of some form of environmental stress, which can inhibit the ability of microalgae to obtain nutrients. Harsh environmental conditions inhibit the formation of proteins and the growth of microalgae cells. Carbon that is not processed into protein is converted into lipids and collected as a form of emergency food reserve (Karima et al., 2018).

Table 2 Biomass lipid extraction from Agathis

\begin{tabular}{cccccc}
\hline $\begin{array}{c}\text { Sampling } \\
\text { Station }\end{array}$ & $\begin{array}{c}\text { Total of } \\
\text { Sample (l) }\end{array}$ & $\begin{array}{c}\text { Biomass } \\
\text { Weight (g) }\end{array}$ & $\begin{array}{c}\text { Lipid } \\
\text { Weight (g) }\end{array}$ & $\begin{array}{c}\text { Percentage of } \\
\text { Biomass /Total } \\
\text { Sample (\%) }\end{array}$ & $\begin{array}{c}\text { Lipid } \\
\text { Percentage/g } \\
\text { Biomass (\%) }\end{array}$ \\
\hline Inlet & 20 & 7.76 & 5.25 & 0.03 & $\mathbf{6 7 . 7}$ \\
Midlet & 20 & 8.69 & 3.83 & 0.04 & $\mathbf{4 4 . 1}$ \\
Outlet & 20 & 8.73 & 4.91 & 0.04 & $\mathbf{5 6 . 3}$ \\
\hline Total & 60 & 25.18 & 13.99 & 0.04 & $\mathbf{5 5 . 5}$ \\
\hline
\end{tabular}

\subsection{Potential Lipid Content of Microalgae Communities in Agathis}

The results of observing water samples under a microscope showed 11 species of microalgae in water samples taken from Agathis in the rainy season. These microalgae species come from 10 genera and four classes of microalgae. Of the 10 genera, eight are known to have varying lipid contents. The lipid content of each genus ranged from $2.86 \%$ to 20.31\%, as follows: Eudorina 3\%, Scenedesmus 10\%, Euglena 4\%, Oscillatoria 5\% 
(Prabakaran and Ravindran, 2011), Closterium 20.31\% (Karima et al., 2018), Arthrospira 7.8\% (Mendes et al., 2006), Limnothrix 7.87\% (de Oliveira et al., 2018), and Pinnularia $2.86 \%$ (Khan et al., 2020).

Based on lipid content data obtained from the literature, theoretical lipid content per microalgae species can be estimated. The theoretical lipid content of Agathis microalgae can be estimated by multiplying the dominance percentage $\left(D_{i}\right)$ and the microalgae lipid content based on the literature (Phatarpekar et al., 2000). The results of the theoretical lipid content estimation of microalgae from Agathis can be seen in Table 3.

The estimated lipid content of the Agathis microalgae community was lower than the results obtained by extraction. There are two possible causes for the extraction results, which are more than the theoretical results. The first possibility is that there is an environmental influence on the microalgae community that can increase lipid levels, such as environmental stress and dissolved nutrient levels (Karima et al., 2018). The second possibility is the presence of other microorganisms that contribute to increasing lipid levels in the biomass (McBride et al., 2014).

Table 3 Theoretical lipid content of microalgae from Agathis

\begin{tabular}{|c|c|c|c|c|}
\hline \multirow[t]{2}{*}{ Class and Genus/Species } & \multicolumn{4}{|c|}{$\begin{array}{c}\text { Theoretical Lipid Content (Percentage of Dominance } \times \text { Lipid } \\
\text { Content based on Literature) }(\%)\end{array}$} \\
\hline & Inlet & Midlet & Outlet & Average \\
\hline \multicolumn{5}{|l|}{ Chlorophyceae } \\
\hline Eudorina sp. & 2.7388 & 2.7245 & 2.5298 & 2.7195 \\
\hline Closterium sp. & 0.1336 & 0.0418 & 0.0326 & 0.0680 \\
\hline Scenedesmus sp. & - & 0.0018 & $0.005 \%$ & 0.0013 \\
\hline \multicolumn{5}{|l|}{ Euglenophyceae } \\
\hline Euglena viridis & 0.0562 & 0.0705 & 0.1313 & 0.0635 \\
\hline Euglena spirogyra & 0.0222 & 0.0158 & 0.0495 & 0.0172 \\
\hline \multicolumn{5}{|l|}{ Cyanophyceae } \\
\hline Arthrospira sp. & 0.0009 & - & - & 0.0004 \\
\hline Oscillatoria sp. & 0.1581 & 0.1849 & 0.1480 & 0.1702 \\
\hline Limnothrix sp. & 0.1107 & 0.1299 & 0.2033 & 0.1313 \\
\hline \multicolumn{5}{|l|}{ Bacillariophyceae } \\
\hline Pinnularia sp. & 0.0106 & 0.0128 & 0.06662 & 0.0176 \\
\hline Total & 3.2315 & 3.1822 & 3.1663 & 3.1893 \\
\hline
\end{tabular}

The amount of biomass obtained directly from Agathis is still insufficient to meet industrial needs. Estimates based on the literature require at least $15 \mathrm{~g}$ of biomass obtained per square meter of land daily for lipid production to be economical (Shen et al., 2009). From each station, the average biomass obtained from Agathis per square meter is $8.394 \mathrm{~g}$. The data obtained may also be affected by the harvesting equipment, which is still a laboratory-scale harvesting tool.

The average lipid content of the biomass from Agathis water samples and the lipid content of the biomass from the midlet and outlet are still insufficient for economical lipid production, which is $60 \%$. A more adequate lipid content resulted from the extraction of water sample biomass from the inlet, which was $67.7 \%$.

Lipid content produced by biomass from Agathis can be produced by microorganisms not classified as microalgae. Microorganisms that can be found in the biomass are zooplankton, yeast, and bacteria. The impact and handling of the presence of other microorganisms in the biomass can be determined by conducting separate studies to deal with the presence of non-microalgae microorganisms (McBride et al., 2014). 
Overall, the biomass obtained from Agathis water samples during the rainy season has the potential to be used as a lipid source. Eight out of 10 genera of microalgae from Agathis are known to produce lipids, and the lipid content of the biomass from Agathis has exceeded the theoretical calculation and reaches or approaches the minimum lipid content needed for economical lipid production. The average yield of lipid extraction from Agathis was $55.5 \%$, exceeding the estimate of $3.1893 \%$.

\subsection{Utilization of UHM for Direct Harvesting of Mixed Culture from Agathis}

As mentioned earlier, the biomass data obtained still does not meet industry-scale standards, likely due to the laboratory-scale harvesting tools. The tool (UHM) uses an ultrasound generator that produces $1.7-\mathrm{MHz}$ waves and uses a good 25 Watts of electrical energy (Ardiansyah et al., 2020). Therefore, to achieve the standard weight of industrialscale biomass, it is still necessary to optimize the harvesting equipment used. The UHM equipment used must still be developed and refined for use in field-scale harvesting.

This study shows that the UHM can be used for mixed cultures on a larger scale than ordinary ponds such as small lakes. This is because in small lakes, it is also possible to find microalgae cells and other microorganisms that are larger in size, and the density of microalgae cells and other microorganisms in small lakes is also greater when compared to ordinary ponds. In the results of a previous study comparing monocultures (Synechococcus) and mixed cultures (fishpond), cell size and cell density were known to affect the accumulation of microalgae biomass using a UHM (Ardiansyah et al., 2020). Mixed-culture biomass is easier to accumulate because of the variable size and shape of the cells. In addition, cell density affects the sedimentation process during biomass accumulation using the UHM.

\section{Conclusions}

The results of the research are as follows. In total, 11 species of microalgae were identified in Agathis in the rainy season. The microalgae community in Agathis was dominated by Eudorina sp., with an average dominance percentage of $90.652 \%$. The average theoretical lipid content of the biomass obtained from Agathis is $3.1893 \%$, and the lipid content of the biomass from the Agathis water sample exceeded the theoretical lipid content of $55.5 \%$. The lipid content of the biomass from the Agathis water samples is insufficient for industrial scale, but it has the potential to be used as a more adequate lipid source. The development and improvement of the UHM will be carried out for use in fieldscale harvesting.

\section{Acknowledgements}

This work was funded by the grant of Hibah PDUPT 2021 from the Ministry of Research and Technology/National Research and Innovation Agency (Kementerian Riset dan Teknologi/BRIN) Indonesia to Dr. Nining Betawati Prihantini, M.Sc., grant number: NKB178/UN2.RST/HKP.05.00/2021.

\section{References}

Alalwan, H., Aba, A.H., Aljaafari, H., 2019. Promising Evolution of Biofuel Generations. Subject Review. Renewable Energy Focus, Volume 28, pp. 127-139

American Public Health Association (APHA), 2005. Standard Methods for the Examination for Water and Wastewater. 21 ${ }^{\text {st }}$ Edition. American Water Works Association (AWWA), Washington 
Ardiansyah, S.R., Orlando, A.M., Rahman, A., Nasruddin, Prihantini, N.B., 2020. Preliminary Design of Microalgal Biomass Harvesting Module using Ultrasound Wave Trapping Principle. In: AIP Conference Proceeding, Volume 2255, https://doi.org/10.1063/5.0013545

Badan Meteorologi Klimatologi dan Geofisika, 2019. Prakiraan Musim Hujan 2019/2020 di Indonesia (Prediction of Rainy Season in Indonesia 2019/2020). BMKG Jakarta, Jakarta

Bligh, E.G., Dyer, W.J., 1959. A Rapid Method of Total Lipid Extraction and Purification. Canadian Journal of Biochemistry and Physiology, Volume 37(8), pp. 911-917

Bold, H.C., Wynne, M.J., 1985. Introduction to the Algae: Structure and Reproduction. Prentice-Hall, Englewood Cliffs, New Jersey

Brönmark, C., Hansson, L.A., 2017. The Biology of Lakes and Ponds. Oxford University Press, Oxford

Cercado, A.P.I., Ballesteros Jr., F.C., Capareda, S.C., 2018. Biodiesel from Three Microalgae Transesterification Processes using Different Homogenous Catalysts. International Journal of Technology, Volume 9(4), pp. 645-651

Cox, G.W., 1995. Laboratory Manual of General Ecology. $7^{\text {th }}$ Edition. Wm. C. Brown Company Publisher, Dubuque

Dalrymple, O.K., Halfhide, T, Udom, I., Gilles, B., Wolan, J., Zhang, Q., Ergas, S., 2013. Wastewater Use in Algae Production for Generation of Renewable Resources: A Review and Preliminary Results. Aquatic Biosystems, Volume 9(2), pp. 1-11

de Oliveira, D. T., Vasconcelos, C. T., Feitosa, A. M. T., Aboim J. B., de Oliveira, A. D. N., Xavier, L. P., Santos, A. S., Gonçalves E. C., da Rocha Filho, G. N., do Nascimento, L. A. S., 2018. Lipid profile analysis of three new Amazonian cyanobacteria as potential source of biodiesel. Fuel 234, pp.785-788

Direktorat Umum dan Fasilitas Universitas Indonesia., 2009. Syarat-syarat Teknis Pekerjaan Pemeliharaan Kebersihan dan Keindahan Danau Kampus Depok Universitas Indonesia (Technical Requirements for Maintaining the Cleanliness and Beauty of the Lake in the Depok Campus, University of Indonesia). Pembinaan Lingkungan Kampus Universitas Indonesia, Depok

Edmonson, W.T., 1960. Freshwater Biology $2^{\text {nd }}$ Edition. John Wiley \& Sons Inc., New York

Fasaei, F., Bitter, J.H., Slegers, P.M., van Boxtel., A.J.B., 2018. Techno-economic Evaluation of Microalgae Harvesting and Dewatering Systems. Algal Research, Volume 31, pp. 347362

Geitler, L., 1985. Cyanophyceae. Koeltz Scientific Books, Koenigstein

Hoek, C.V.D., Mann, D.G., Jahns, H.M., 1995. Algae: An Introduction to Phycology. Cambridge University Press, Cambridge

Karima, A., Silalahi, M.D.S., Rinanti, A., 2018. Increasing Content of Lipid in Tropical Microalgae Chlorella sorokiniana and Closterium Sp. With Variation of Nitrogen Content and Extraction Temperature. MATEC Web of Conferences, Volume 197, pp. 1-4

Khan, M.J., Bawra N., Verma, A., Kumar, V., Pugazhendhi, A., Joshi, K.B., Vinayak, V., 2020. Cultivation of Diatom Pinnularia saprophila for Lipid Production: A Comparison of Methods for Harvesting the Lipid from The Cells. Bioresource Technology, Volume 319, https://doi.org/10.1016/j.biortech.2020.124129

Li, Y., Horsman M., Wang B., Wu N., 2008. Effect of Nitrogen Sources on Cell Growth and Lipid Accumulation of Green Algae Neochloris oleoabundanss. Applied Microbiol Biotechnology, Volume 81(4), pp. 629-636

Little, A.E.F., Robinson, C.J., Peterson, S.B., Raffa, K.E., Handelsman, J., 2008. Rules of Engagement: Interspecies Interactions That Regulate Microbial Communities. Annual Review of Microbiology, Volume 62, pp. 375-401 
Mat Aron, N.S., Khoo, K.S., Chew, K.W., Show, P.L., Chen, W., Nguyen, H.P., 2020. Sustainability of the Four Generations of Biofuels-A Review. International Journal of Energy Research, Special Issue: Sustainable Energy and Green Technologies, Volume 44 (12), pp. 9266-9282

Maulana, F., Wardhana, W., Nasruddin, Prihantini, N.B., 2021. The Potency of Microalgal Biomass from Agathis Small Lake, Universitas Indonesia as Biofuel Source: Study of Dry Season Wild Mix-Culture. In: AIP Conference Proceedings, Volume 2376, https://doi.org/10.1063/5.0064316

McBride, R.C., Lopez, S., Meenach, C., Burnett, M., Lee, P.A., Nohilly, F., Behnke, C., 2014. Contamination Management in Low-Cost Open Algae Ponds for Biofuels Production. Industrial Biotechnology, Volume 10(3), pp. 221-227

Mendes, R.L., Reis, A.D., Palavra A.F., 2006. Supercritical $\mathrm{CO}_{2}$ Extraction Of $\Gamma$-Linoleic Acid and Other Lipids from Arthrospira (Spirulina) maxima: Comparison with Organic Solvent Extraction. Food Chemistry, Volume 99(1), pp. 57-63

Mousavi, S., Najafpour, G.D., Mohammadi, M., Seifi, M.H., 2018. Cultivation of Newly Isolated Microalgae Coelastrum sp. in Wastewater for Simultaneous $\mathrm{CO}_{2}$ Fixation, Lipid Production, and Wastewater Treatment. Bioprocess and Biosystem Engineering, Volume 41(4), pp. 519-530

Phatarpekar, P.V., Sreepada, R.A., Pednekar, C., Achuthankutty, C.T., 2000. A Comparative Study on Growth Performance and Biochemical Composition of Mixed Culture of Iscochrysis galbana and Chaetoceros calcitrans with Monocultures. Aquaculture, Volume 181(1), pp. 141-155

Pentecost, A., 1984. Introduction to Freshwater Algae. Richmond Publishing Co. Ltd., England

Prabakaran, P., Ravindran, A.D., 2011. A Comparative Study on Effective Cell Disruption Methods for Lipid Extraction from Microalgae. Letters in Applied Microbiology, Volume 53(2), pp. 150-154

Prihantini, N.B., Wardhana, W., 2016. Cyanobacteria in Sunter II Lake of North Jakarta and Agathis Small Lake of Universitas Indonesia in 2003, 2006, and 2012. In: AIP Conference Proceeding, Volume 1729(1), https://doi.org/10.1063/1.4946968

Rizaldi, M.I., Rahman, A., Deendarlianto, Prihantini, N.B., Nasruddin, 2019. Generation of Microbubbles Through Single Loop and Double Loop Fluid Oscillator for Photobioreactor Aeration. International Journal of Technology, Volume 10(7), pp. 1446-1452

Santoso, Y.A., Tambunan, R.M.N., Soekirno, S., Nasruddin, Prihantini, N.B., 2020. Sound Wave Exposure as a Strategy for Improving the Tubular Photobioreactor for Cultivating Synechococcus HS-9 as Biofuel Feedstock under Different Photoperiods. International Journal of Technology, Volume 11(7), pp. 1406-1413

Sathish, A., Sims, R.C., 2012. Biodiesel Production from Mixed Culture Algae via a Wet Lipid Extraction Procedure. Bioresource Technology, Volume 118, pp. 643-647

Shen, Y., Yuan, W., Pei, Z.J., Wu, Q., Mao, E., 2009. Microalgae Mass Production Methods. American Society of Agricultural and Biological Engineers, Volume 52(4), pp. 12751287

Singh, A., Nigam, P.S., Murphy, J.D., 2011. Renewable Fuels from Algae: An Answer to Debatable Land-Based Fuels. Bioresource Technology, Volume 102(1), pp. 10-16

Whitton, B.A., 2002. Phylum Cyanophyta (Cyanobacteria). The Freshwater Alga Flora of The British Isles: An Identification Guide to Freshwater and Terrestrial Algae, Jhon, D.M., Whitton, B.A., Brook, A. J. (eds.), Cambridge University Press, Cambridge 